\title{
No effect of glucagon-like peptide-1 on short-term satiety and energy intake in man
}

\author{
S. J. Long ${ }^{1}$, J. A. Sutton ${ }^{3}$, W. B. Amaee ${ }^{2}$, A. Giouvanoudi ${ }^{2}$, N. M. Spyrou ${ }^{2}$, P. J. Rogers ${ }^{4}$ \\ and L. M. Morgan ${ }^{1 *}$ \\ ${ }^{1}$ School of Biological Sciences and ${ }^{2}$ Department of Physics, University of Surrey, Guildford GU2 5XH, UK \\ ${ }^{3}$ Guildford Clinical Pharmacology Unit, Royal Surrey County Hospital, Guildford GU2 5XX, UK \\ ${ }^{4}$ Institute of Food Research, Reading Laboratory, Reading RG6 2EF, UK
}

(Received 8 September 1998 - Revised 29 October 1998 - Accepted 6 November 1998)

\begin{abstract}
Centrally administered glucagon-like peptide-1 (GLP-1) inhibits feeding in fasted rats, but its role in human satiety has been largely unexplored. The present study investigated the effect of peripheral GLP-1 infusion on gastric emptying and satiety in man. Ten non-obese male subjects were infused in a randomized single-blind within-subject crossover study using saline infusion as control. They received either a GLP-1 infusion ( $1.2 \mathrm{pmol} / \mathrm{kg}$ per $\mathrm{min})$ or a saline infusion for $1 \mathrm{~h}$, at 18.00 hours. At $20 \mathrm{~min}$ after starting the infusion the gastric emptying of a $400 \mathrm{ml}$ water load was measured. Subjects completed behavioural self-rating scales to assess hunger and satiety. After 40 min subjects were given a buffet meal ad libitum and their food intake was recorded. GLP-1 infusion raised circulating GLP-1 concentrations to approximately twice those seen following a meal. It did not affect circulating insulin levels but caused a small fall in glucose levels. Gastric emptying of the water load was significantly delayed by the GLP-1 infusion. Energy intake from the buffet was unaffected by GLP-1 infusion. Self-assessment of hunger and satiety was similarly unaffected by the infusion before the buffet meal, although subjects tended to be less hungry after the buffet meal following GLP-1 infusion $(P<0 \cdot 09)$. GLP-1 infusion delayed gastric emptying but had a minimal effect on food intake and satiety. This study casts doubts on whether GLP-1 is a major satiety factor in man, although a raised circulating plasma glucose level, as would normally occur postprandially, might be necessary for GLP-1 to increase satiety.
\end{abstract}

\section{Glucagon-like peptide-1: Food intake: Satiety: Gastric emptying}

There has been an increasing trend towards obesity in many Western countries over the last 20 years. In the UK, for example, the proportion of adults classified as obese on the basis of BMI $>30 \mathrm{~kg} / \mathrm{m}^{2}$ doubled between 1980 and 1991 (Prentice \& Jebb, 1995). In general, food intake has not decreased sufficiently to compensate for the decline in energy expenditure brought about by contemporary labour-saving lifestyles, focusing attention on the mechanisms by which nutrient intake is controlled.

Relatively little is known about the biochemical mechanisms that contribute to hunger and satiety. The initiation and termination of feeding are complex processes that are likely to involve multiple signals to the central nervous system. However, there is strong evidence that the short-term control of food intake is mediated via satiety signals in the form of gastrointestinal hormones, whose secretion is triggered by the presence of food, especially fat, in the intestine (Welch et al. 1985).

Nutrient ingestion stimulates the release of a number of duodenal and ileal gastrointestinal hormones. Most work has centred on cholecystokinin (CCK) as a hormonal satiety signal. There is strong evidence from animal studies to implicate CCK as a peripheral satiety signal (Lotti et al. 1987), although the evidence in man is less clear. Physiological doses of peripherally administered CCK have a satiating effect in human subjects (Lieverse et al. 1995), but conflicting results have been obtained when peripheral CCK receptor antagonists have been administered (Wolkowitz et al. 1990; Drewe et al. 1992). CCK has multiple effects on the gastrointestinal tract, including the modulation of gastric emptying, which may influence satiety (Moran \& McHugh, 1992)

In view of the conflicting evidence implicating CCK as a satiety factor in man, it seems likely that other gastrointestinal hormones are also involved in human satiety. The gastrointestinal hormone glucagon-like peptide-1(7-36)amide (GLP-1) is secreted from the ileum in response to fat, carbohydrate and protein intake in man (Elliott et al. 1993). 
Table 1. Macronutrient and energy content of the standard lunchtime meals (Nutritional values per meal)

\begin{tabular}{lccccr}
\hline Meal & $\begin{array}{c}\text { Energy } \\
(\mathrm{kJ})\end{array}$ & $\begin{array}{c}\text { Protein } \\
(\mathrm{g})\end{array}$ & $\begin{array}{c}\text { Fat } \\
(\mathrm{g})\end{array}$ & $\begin{array}{c}\text { Carbohydrate } \\
(\mathrm{g})\end{array}$ & $\begin{array}{c}\text { NSP } \\
(\mathrm{g})\end{array}$ \\
\hline Chicken pasta bake & 1456 & 20.9 & 12.9 & 37.4 & 0.5 \\
Cheese and onion bake & 1644 & 14.5 & 19.1 & 40.5 & 1.2 \\
Tagliatelli carbonara & 1406 & 17.3 & 14.1 & 35.2 & 1.9 \\
\hline
\end{tabular}

Best known for its insulin stimulatory action (Kreymann et al. 1987), it inhibits both gastric emptying and gastric acid secretion, properties it shares with CCK (Wettergren et al. 1993). GLP-1 has been shown to be a central satiety factor in rats; intracerebroventricular infusion of GLP-1 depresses food intake, a situation reversed by the administration of GLP-1 antibodies or receptor antagonists (Turton et al. 1995; Tang Christensen et al. 1996). We have found that GLP-1 levels are lower postprandially in obese than normal-weight subjects (Ranganath et al. 1996), a finding that reinforces the hypothesis that GLP-1 may play an important role in satiety. However, there is evidence that central infusion of GLP-1 produces conditioned taste aversion in rats and may not, therefore, act as a true satiety factor (Thiele et al. 1997).

Peripheral GLP-1 has the ability to access the brain via the subfornical organ and the area postrema of the circumventricular organs (Orskov et al. 1996) where the bloodbrain barrier is leaky. Intravenously infused GLP-1, when co-infused with a fixed-energy breakfast, has recently been shown to increase subjective feelings of satiety and suppress subsequent energy intake in man (Flint et al. 1998). The present study was designed to examine the effect of intravenous GLP-1 infusion administered both postabsorptively and during a meal, on subjective feelings of hunger and satiety and the energy intake of an ad libitum buffet meal, in non-obese human subjects. GLP-1 infusion rates were calculated to elicit circulating GLP-1 levels in the upper range of normal postprandial levels, and the effect of GLP-1 infusion on gastric emptying was also measured using electrical impedance epigastrography, to ascertain the possible contribution that alterations in gastric emptying might make to satiety.

\section{Materials and methods}

\section{Study design}

A single-blind randomized within-subject crossover comparison of GLP-1 and placebo for their effects on appetite, gastric emptying and circulating hormone and metabolite concentrations was performed.

\section{Subjects}

Ten male subjects aged $20-29$ years, BMI $20-27 \mathrm{~kg} / \mathrm{m}^{2}$, were recruited. They were non-dieters and non-smokers, consuming $<20$ units alcohol/week, and were free from significant medical history. Subjects were asked to complete the Dutch eating behaviour questionnaire (Van Strien et al. 1986) before acceptance on to the study. This determines the extent to which individuals respond to external and emotional cues when eating and helped to ensure that only individuals with 'normal' eating habits were recruited. Written and oral consent was obtained from each subject before the start of the study and standard biochemical and haematology screening was conducted before inclusion of subjects into the study. Ethical approval for the study was obtained from the South West Surrey District and University of Surrey Ethical Committees.

\section{Experimental protocol}

Subjects were studied on two occasions, $7 \mathrm{~d}$ apart. They were asked to refrain from strenuous exercise and alcohol intake both on the study day and on the previous day. On each occasion subjects were asked to eat their usual breakfast on the morning of the study, but to avoid fried and highfat foods and caffeinated drinks. They consumed a standard lunch at 12.00 hours, selected from a range of oven-ready meals relatively low in fat and NSP content, both of which may have variable and prolonged effects on gastric emptying (Table 1). The same lunch was consumed on both occasions. Subjects were instructed to eat nothing further and drink only water during the afternoon. At 17.00 hours two intravenous cannulas were inserted, one into each forearm. Three pairs of electrodes were positioned over the stomach and lower back to measure gastric emptying by electrical impedance epigastrography. Baseline impedance readings were taken for $10 \mathrm{~min}$ during this time and subjects completed a basal set of self-rating visual analogue scales (VAS) for hunger, satiety and any adverse effects of the infusion (nausea, headache, abdominal discomfort). Two basal blood samples were taken into sterile containers. GLP-1 and saline solutions were infused in random order for $60 \mathrm{~min}$. Synthetic GLP-1 was supplied by Professor S. Bloom, Royal Postgraduate Medical School, London, UK. The material was $>99 \%$ pure, $>85 \%$ peptide content with a molecular mass of $3295 \cdot 32$ as determined by mass spectrometry. GLP-1 (10 nmol) was diluted to $50 \mathrm{ml}$ with saline into which was mixed $0.5 \mathrm{ml}$ plasma from the subject's basal blood sample, in order to ensure stability of GLP-1 and minimize adsorption of the peptide onto the syringe and tubing surfaces. The infusion rate was calculated to provide $1 \cdot 2 \mathrm{pmol}$ GLP- $1 / \mathrm{kg}$ per min, which previous studies (Willms et al. 1996) have indicated results in plasma GLP-1 concentrations similar to those found after a meal. At $20 \mathrm{~min}$ after the start of the infusion subjects were given $400 \mathrm{ml}$ water to drink and gastric emptying was monitored for $20 \mathrm{~min}$. Subjects completed three further self-rating VAS. Venous blood was collected at $10 \mathrm{~min}$ intervals for hormone and metabolite measurement. At $40 \mathrm{~min}$ after the start of the infusion subjects were offered buffet meals and their food 
intake and choice monitored. They were given a further $200 \mathrm{ml}$ water to drink with their meal.

\section{Chemical analyses}

Blood was collected into tubes containing fluoride oxalate and EDTA for the measurement of glucose and non-esterified fatty acids respectively, by standard automated spectrophotometric methods. The interassay CV were $<5 \%$ for these assays. Blood was collected into lithium-heparinized tubes for the measurement of plasma insulin and GLP-1 by radioimmunoassay (Elliott et al. 1993; Hampton \& Withy, 1993). Tubes for GLP-1 measurement contained, in addition, $200 \mathrm{KIU}$ aprotinin $/ \mathrm{ml}$ blood. The plasma was separated immediately at $4^{\circ}$ and frozen at $-20^{\circ}$. Assay sensitivities were 19 and $8 \mathrm{pmol} / \mathrm{l}$ respectively and the interassay $\mathrm{CV}<10 \%$ for both assays.

\section{Gastric emptying measurement}

Gastric emptying was measured by electrical impedance epigastrography using previously established methods (McLelland \& Sutton, 1985; Spyrou \& Castillo, 1993). This technique measures the difference in electrical conductivity of a meal within the stomach and that of the surrounding tissues, and their changes over time. The value of the electrical impedance is proportional to the volume of the meal remaining in the stomach. The half-time of gastric emptying (T50) was defined as the time taken to return to $50 \%$ of the peak signal produced in response to the water load. The shape of the emptying curve after the initial lag period is of a multiexponential form (WB Amaee, A Giouvanoudi and NM Spyrou, unpublished results).

\section{Assessment of appetite}

Subjective feelings of hunger and satiety were measured with validated self-rating $100 \mathrm{~mm}$ VAS (Rogers \& Blundell, 1979). The subjective ratings on the scales were converted to a score in millimetres for statistical analysis, allowing comparison of the hunger and satiety response to each treatment. Food preference checklists were completed at the same time as the VAS (Rogers, 1993). Ad libitum food intake and choice was measured by serving subjects with a buffet-style meal consisting of a range of familiar foods appropriate to the time of day (Rogers, 1993). Subjects were instructed to eat until they were comfortably full and their food intake and choice recorded. Whilst eating subjects were screened off from one another to minimize the effects of social interaction on food intake.

\section{Statistical analyses}

VAS profiles were analysed by analysis of covariance, with treatment and time as the repeated factors. Hormone and metabolite data were analysed by repeated-measures ANOVA with treatment and time as within-subject factors. T50 values were compared using a Student's paired $t$ test. $P$ values of $<0.05$ were considered statistically significant. Results are expressed as means with their standard errors unless otherwise stated.

\section{Results}

The GLP-1 infusion was well tolerated by the subjects. No nausea, abdominal discomfort, headache or any other adverse side-effects were reported with either infusion.

\section{Hormone and metabolite concentrations}

Plasma GLP-1, insulin and glucose levels are shown in Fig. 1. GLP-1 infusion raised circulating GLP-1 levels within $10 \mathrm{~min}$ to approximately twice normal postprandial levels; these remained elevated throughout the study period. GLP-1 levels were unaffected by saline infusion. Plasma insulin levels were unaffected by either infusion. Following the buffet meal, plasma insulin levels were significantly lower $(P<0 \cdot 01)$ with the GLP-1 infusion than the saline infusion.

GLP-1 infusion caused a small but significant drop in circulating glucose level from 4.9 (SE 0.1) to 4.1 (SE 0.1) $\mathrm{mmol} / \mathrm{l}(P<0.01)$ by $40 \mathrm{~min}$. Following the buffet meal, plasma glucose levels were significantly lower $(P<0 \cdot 01)$ with the GLP-1 infusion than the saline infusion.

\section{Gastric emptying}

The gastric emptying of the water load is shown in Fig. 2. GLP-1 infusion caused a more pronounced lag period at the beginning of the emptying curve and significantly delayed the half emptying time of the water load. The T50 was 7.0 (SE 0.5) min for the saline infusion $v .11 .8$ (SE 1.1) min for the GLP-1 infusion $(P<0 \cdot 01)$.

\section{Assessment of appetite}

Subjective ratings of hunger and fullness were unaffected by GLP-1 or saline infusion. Hunger levels decreased and fullness levels increased significantly following the buffet meal for both infusions. There was a tendency for subjects to be less hungry after the buffet meal following GLP-1 infusion (hunger rating 2.6 (SE 0.7) for saline v. 1.4 (SE 0.2) for GLP-1, $P<0.09$ ). Subjective ratings for hunger are shown in Fig. 3. GLP-1 infusion did not affect either the number of items or the total energy value of foods chosen on the food preference checklists. Mean energy intake from the buffet was lower with the GLP-1 infusion (5903 (SE 358) v. 5485 (SE 540) kJ) but the differences failed to achieve significance $(P=0 \cdot 27)$. Data from individual subjects are shown in Fig. 4. There were no differences in either the macronutrient content or weight of food consumed in the buffet meal between the GLP-1 and saline infusions.

\section{Discussion}

Intravenous infusion of GLP-1 achieved mean circulating levels of the hormone which were approximately twice as high as those achieved in the control conditions following the buffet meal. They were similar to maximal postprandial values we have observed previously in some individuals following a 2.51 MJ liquid meal (SJ Long and LM Morgan, unpublished results). Thus, circulating GLP-1 levels at the upper end of the normal physiological range were achieved in this study. High doses of exogenous GLP-1 can cause nausea and vomiting (Ritzel et al. 1995). However, in the present study the infusions were well tolerated and no adverse effects were reported. 


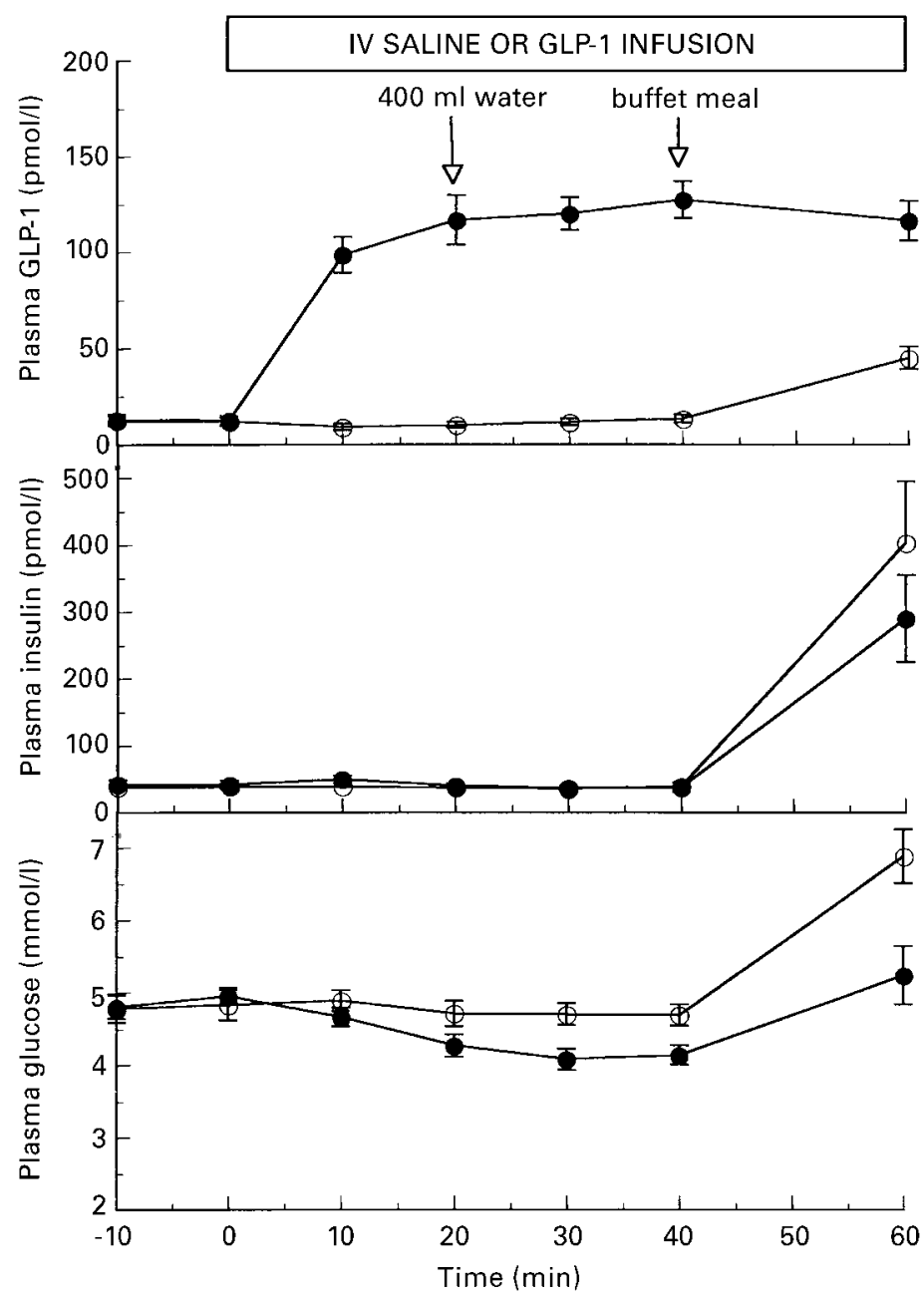

Fig. 1. Plasma glucagon-like peptide-1 (GLP-1), insulin and glucose levels in healthy subjects following the intravenous (IV) infusion of either saline (O) or $1.2 \mathrm{pmol}$ GLP-1/kg per min (๑) for 60 min during which water and a buffet meal were consumed. Values are means for ten subjects, with their standard errors represented by vertical bars.

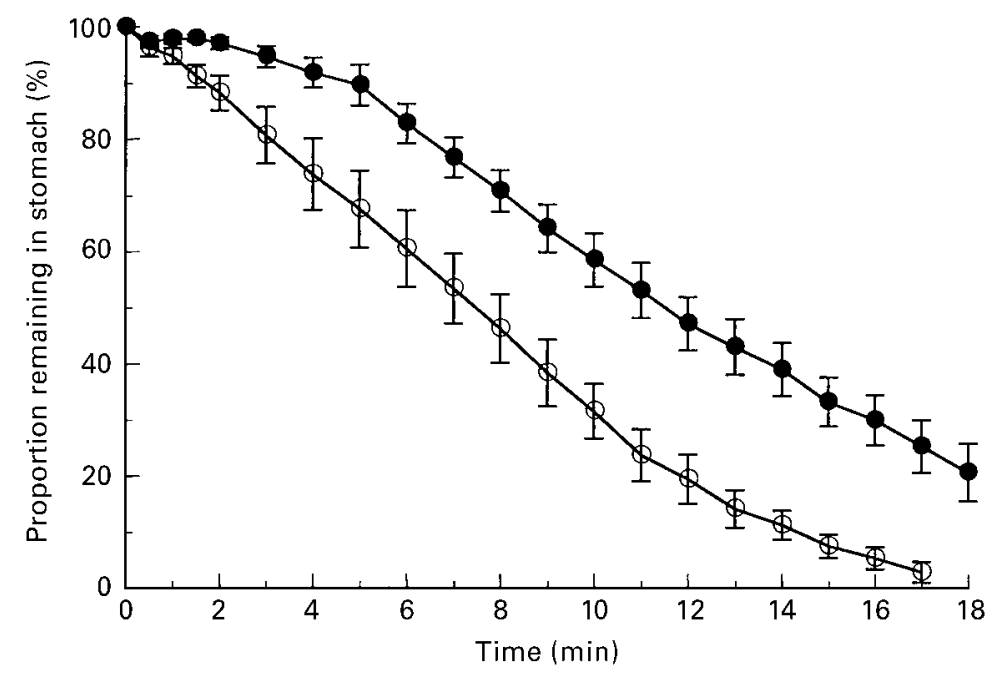

Fig. 2. Gastric emptying rates of a $400 \mathrm{ml}$ water load in healthy subjects during intravenous infusion of either saline $(O)$ or $1.2 \mathrm{pmol}$ glucagon-like peptide-1 (GLP-1)/kg per min (๑) for $60 \mathrm{~min}$. Values are means for nine subjects, with their standard errors represented by vertical bars. 


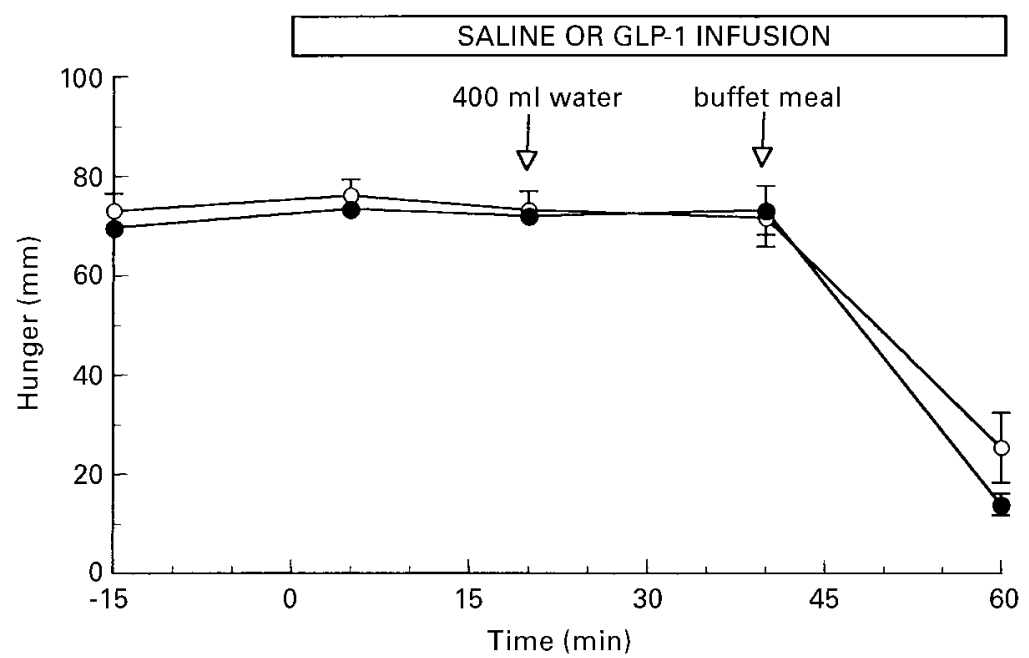

Fig. 3. Subjective ratings of hunger in healthy subjects during the intravenous infusion of either saline $(O)$ or $1.2 \mathrm{pmol}$ glucagon-like peptide-1 (GLP-1)/kg per $\min (\bullet)$ for $60 \mathrm{~min}$, before and after consumption of an ad libitum buffet meal. Values are means for ten subjects, with their standard errors represented by vertical bars.

GLP-1 delayed the gastric emptying of a water load. This finding is in line with previously published work (Wettergren et al. 1993; Schirra et al. 1997) and demonstrates that the GLP-1 infused was biologically active. Schirra et al. (1997) have reported that GLP-1 prolongs the lag period of a $1.26 \mathrm{MJ}$ mixed liquid meal, but has no effect on total emptying time, maximal velocity of emptying or emptying rate. We observed a prolongation of both lag period and half emptying time with a water load. Consistent with the action of GLP-1 in delaying gastric emptying, plasma glucose and insulin levels following the buffet meal were lower when GLP-1 was infused than with the saline infusion. Thus, in the physiological setting of meal ingestion, the well-documented insulinotropic effect of GLP-1, observed when both GLP1 and glucose are infused intravenously, is obscured by its confounding effects on gastric emptying.

In spite of achieving postprandial circulating levels of biologically active GLP-1 with the intravenous infusion, no

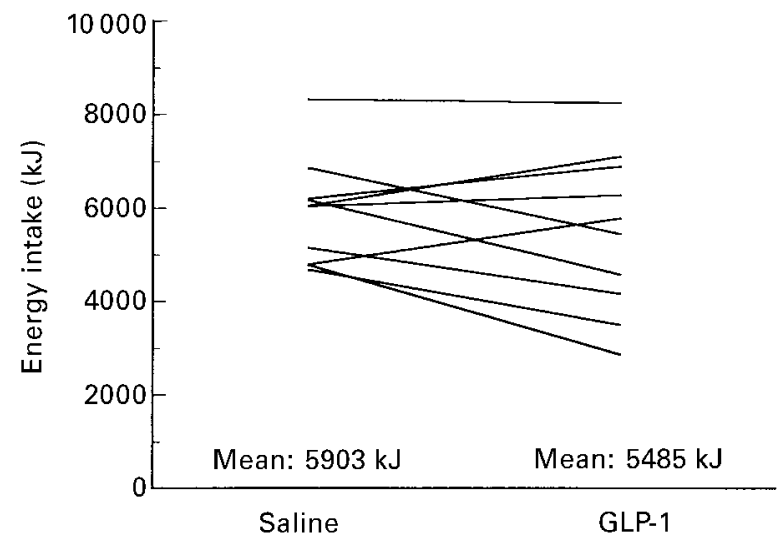

Fig. 4. Energy intakes for individual subjects from an ad libitum buffet meal consumed $40 \mathrm{~min}$ after the start of an intravenous infusion of either saline $(O)$ or $1.2 \mathrm{pmol}$ glucagon-like peptide-1 (GLP-1)/kg per $\min (\bullet)$. significant effects were seen on subjects' subjective ratings of hunger or fullness, or on their buffet meal intake. The only measure that tended to show any difference was subjective feelings of hunger, whose mean level was lower following the buffet meal when GLP-1 was infused in spite of a lower mean buffet intake, providing some indirect evidence that GLP-1 has the ability to enhance the satiating effect of the buffet meal. This, in common with the satiating action of CCK, could be mediated by GLP-1's inhibitory effects on gastric emptying, perhaps associated with distension of the stomach or with an ability to mimic and amplify afferent responses to gastric distension (Read et al. 1994; Ballinger et al. 1995). GLP-1 has been shown to exert effects on antral motility via afferent vagal fibres reaching the brain (Nakabayashi et al. 1996); thus, it is possible that GLP-1 can exert its effects via interaction with sensory nerve fibres in the periphery.

Previous reports on the effect of GLP-1 on satiety in experimental animals have been conflicting. Central intracerebroventricular administration of GLP-1 has been shown to inhibit food intake in rats, a situation reversed by the administration of GLP-1 antibodies or the receptor antagonist exendin (Turton et al. 1995; Tang Christensen et al. 1996). However peripheral (intraperitoneal) administration of GLP-1 has been reported to be ineffective in influencing food intake in rats (Turton et al. 1995; Navarro et al. 1996; Tang Christensen et al. 1996). It has also been claimed (Thiele et al. 1997) that central administration of GLP-1 produces a conditioned taste aversion in rats and therefore does not act as a true satiety agent. The GLP-1 receptor -/mouse, a transgenic animal in which GLP-1 receptors are absent from both pancreas and brain, has permitted analysis of the role of GLP-1 in both glucose control and appetite regulation in vivo. Whilst these mice exhibit glucose intolerance following oral glucose, indicating an essential role for GLP-1 in the regulation of glucose-dependent insulin secretion, they did not demonstrate any significant changes in body weight compared with age and sex-matched control 
mice, or eat more than control mice in short-term feeding studies (Scrocchi et al. 1996). Disruption of GLP-1 signalling to the brain does not, therefore, appear to be essential to the regulation of body weight or satiety in these animals, although it is possible that disruption of GLP-1 signalling from birth may be associated with substantial developmental abnormalities in the central nervous system that influence the regulation of feeding and body weight.

To our knowledge, only three reports have been published concerning the effect of GLP-1 infusion on satiety in human subjects. One of these (Flint et al. 1998) has shown that an intravenous GLP-1 infusion of $50 \mathrm{pmol} / \mathrm{kg}$ per $\mathrm{h}$ over $4 \mathrm{~h}$ affected subjective ratings of hunger and satiety. These effects were more pronounced in the third and fourth hours of infusion and circulating GLP-1 levels were approximately fourfold higher than those achieved postprandially in control subjects. The differences between our findings and those of Flint et al. (1998) may relate to their longer GLP-1 infusion time and relatively greater elevation of circulating GLP-1 compared with normal postprandial levels. A second study in obese subjects (Naslund et al. 1998), in which GLP-1 (0.75 pmol/kg per min) was infused at the start of a lunchtime meal, failed to show any effect of GLP-1 on food intake, consistent with our findings. However, Naslund et al. (1998) demonstrated that when the GLP-1 infusion was continued for $3.5 \mathrm{~h}$ following the meal, postprandial feelings of hunger, desire to eat and prospective food consumption were decreased compared with those after a saline infusion. We monitored subjective feelings of hunger postprandially at only a single time point, 20 min after the start of the buffet meal and after GLP-1 had been infused for only $60 \mathrm{~min}$. We did, however, demonstrate a trend towards lower subjective feelings of hunger postprandially when GLP-1 was infused, in agreement with Naslund's findings. Our study took place in the evening and so we could not measure food intake for the rest of the day. It is, therefore, possible that GLP-1 infusion might affect energy intake in a subsequent meal. The third, a preliminary report (Gutzwiller et al. 1997), demonstrated a reduction in meal intake when GLP-1 was infused with glucose at either 0.75 or $1.5 \mathrm{pmol} / \mathrm{kg}$ per min. However, in this experimental design, which was otherwise very similar to our own, the co-infusion of glucose with GLP-1 would have caused insulin levels to be raised due to the glucose-dependent insulinotropic effect of GLP-1, and this could have affected satiety. In our present study, circulating insulin levels were not affected post-absorptively by GLP-1 infusion because plasma glucose remained at fasting levels. Indeed, we observed a small but significant drop in circulating glucose levels following GLP-1 infusion, which was probably due to insulin-independent effects of GLP-1 in facilitating glucose uptake (Villanueva-Penacarillo et al. 1994) and suppressing glucagon (Komatsu et al. 1989). This may have exerted a confounding effect on our satiety and buffet intake data as glucose also plays a role in the short-term regulation of hunger and food intake (Campfield, 1997).

It is difficult to interpret satiety studies involving the administration of exogenous GLP-1 because of its other biological activities, particularly those which relate to carbohydrate metabolism, and uncertainty as to whether physiological or supraphysiological circulating levels of the hormone are achieved, particularly when the hormone is infused over a period of many hours. The lack of any clear effect of GLP-1 on satiety in the present study in spite of its significant effect on gastric emptying could be explained by the greater variability of behavioural compared with physiological responses. Our study must, however, cast some doubts on whether GLP-1 is a major satiety factor in man. Further work is necessary to determine whether the satiety effect of GLP-1 is dependent on prevailing circulating glucose levels. Resolution of some of the difficulties involved in the interpretation of GLP-1 infusion studies could be achieved with studies involving the neutralization of endogenous GLP-1 using the GLP-1 receptor antagonist exendin, which has been used very recently in human studies to elucidate further the insulinotropic effects of GLP-1 (Schirra et al. 1998).

\section{Acknowledgement}

This work was supported by the Biotechnology and Biological Sciences Research Council.

\section{References}

Ballinger A, McLoughlin L, Medbak S \& Clark M (1995) Cholecystokinin is a satiety hormone in humans at postprandial physiological concentrations. Clinical Science 89, 375-381.

Campfield LA (1997) Metabolic and hormonal control of food intake: highlights of the last 25 years 1972-1997. Appetite 29, $135-152$.

Drewe J, Gadient A, Rovati LC \& Beglinger C (1992) Role of circulating cholecystokinin in control of fat-induced inhibition of food intake in humans. Gastroenterology 102, 16541659.

Elliott RM, Morgan LM, Tredger JA, Deacon S, Wright J \& Marks V (1993) Glucagon-like peptide-1(7-36) amide and glucosedependent insulinotropic polypeptide secretion in response to nutrient ingestion in man: acute postprandial and $24 \mathrm{~h}$ secretion patterns. Journal of Endocrinology 138, 159-166.

Flint A, Raben A, Astrup A \& Holst JJ (1998) Glucagon-like peptide-1 promotes satiety and suppresses energy intake in humans. Journal of Clinical Investigation 101, 515-512.

Gutzwiller JP, Goke B, Drewe J, Ketterer S, Handschin D, Hildebrand P, Winterhalder R, Conen D \& Beglinger C (1997) Glucagon-like peptide-1 is a physiologic regulator of food intake in humans. Gastroenterology 112, A1153.

Hampton SM \& Withy L (1993) Monitoring B cell responses in obese and normal weight subjects. Diabete et Metabolisme 19, 582-585.

Komatsu R, Matsuyama T, Namba M, Watanabe N, Itoh H \& Tauri S (1989) Glucagonostatic and insulinotropic actions of glucagon-like peptide-1-(7-36)amide. Diabetes 38, 902-905.

Kreymann B, Yiangou Y, Williams G \& Bloom SR (1987) Glucagon-like peptide-1(7-36)amide. A physiological incretin in man. Lancet ii, 1300-1303.

Lieverse RJ, Jansen JB, Masclee AA \& Lamers CB (1995) Satiety effects of a physiological dose of cholecystokinin in humans. Gut 36, 176-179.

Lotti VJ, Pendleton RG, Gould RJ, Hanson HM, Chang RSL \& Clineschmidt BV (1987) In vivo pharmacology of L364,718, a new potent nonpeptide cholecystokinin receptor antagonist. Pharmacology Experimental and Therapeutic 241, 103-109.

McLelland GR \& Sutton JA (1985) Epigastric impedance: a noninvasive method for the assessment of gastric emptying and motility. Gut 26, 607-614. 
Moran TH \& McHugh PR (1992) Gastric mechanisms in CCK satiety. In Multiple Cholecystokinin Receptors in the CNS, pp. 182-205 [CT Dourish, SJ Cooper, SD Iversen and LL Iversen, editors]. Oxford: Oxford University Press.

Nakabayashi H, Nishizawa M, Nakagawa A, Takeda R \& Niijima A (1996) Vagal hepatopancreatic reflex effect evoked by intraportal appearance of tGLP-1. American Journal of Physiology 271, E808-E813.

Naslund E, Gutniak M, Skogar S, Rossner S \& Hellstrom PM (1998) Glucagon-like peptide 1 increases the period of postprandial satiety and slows gastric emptying in obese men. American Journal of Clinical Nutrition 68, 525-530.

Navarro M, deFonseca FR, Alvarez EA, Chowen JA, Zueco JA, Gomez R, Eng J \& Blazquez E (1996) Colocalization of glucagon-like peptide-1 (GLP-1) receptors, glucose transporter GLUT-2, and glucokinase mRNAs in rat hypothalamic cells: evidence for a role of GLP-1 receptor agonists as an inhibitory signal for food and water intake. Journal of Neurochemistry $\mathbf{6 7}$, 1982-1991.

Orskov C, Poulsen SS, Moller M \& Holst JJ (1996) Glucagon-like peptide-1 receptors in the subfornical organ and area postrema are accessible to circulating GLP-1. Diabetes 45, 832-835.

Prentice AM \& Jebb SA (1995) Obesity in Britain: gluttony or sloth? British Medical Journal 311, 437-439.

Ranganath LR, Beety JM, Morgan LM, Wright JW, Howland R \& Marks V (1996) Attenuated GLP-1 secretion in obesity: cause or consequence? Gut 38, 916-919.

Read N, French S \& Cunningham K (1994) The role of the gut in regulating food intake in man. Nutrition Reviews 52, 1-10.

Rizel R, Orskov C, Holst JJ \& Nauck MA (1995) Pharmokinetic, insulinotropic, and glucagonostatic properties of GLP-1[736amide] after subcutaneous injection in healthy volunteers: dose-response relationships. Diabetologia 38, 720-725.

Rogers PJ (1993) Experimental investigation of human eating behaviour. In Human Psychopharmacology: Measures and Methods, vol. 4, pp. 123-142 [I Hindmarsh and PD Stonier, editors]. Chichester: Wiley.

Rogers PJ \& Blundell JE (1979) Effects of anorexic drugs on food intake and the microstructure of eating in human subjects. Psychopharmacology 66, 156-165.

Schirra J, Kuwert P, Wank U, Leicht P, Arnold R, Göke B \& Katschinski M (1997) Differential effects of subcutaneous GLP1 on gastric emptying, antroduodenal motility and pancreatic function in men. Proceedings of the Association of American Physicians 109, 84-97.

Schirra J, Sturm K, Leicht P, Arnold R, Göke B \& Katschinski M (1998) Exendin(9-39)amide is an antagonist of glucagon-like peptide-1(7-36)amide in humans. Journal of Clinical Investigation 101, 1421-1430.

Scrocchi LA, Brown TJ, MacLusky N, Brubaker PL, Auerbach AB, Joyner AL \& Drucker DJ (1996) Glucose intolerance but normal satiety in mice with null mutation in the glucagon-like receptor gene. Nature Medicine 2, 1254-1258.

Spyrou NM \& Castillo FD (1993) Electrical impedance measurements. In An Illustrated Guide to GI Motility, pp. 276-289 [D Kumar and DL Wingate, editors]. London: Churchill Livingstone.

Tang Christensen M, Larsen PJ, Goke R, FinkJensen A, Jessop DS, Moller M \& Sheikh SP (1996) Central administration of GLP-1(7-36) amide inhibits food and water intake in rats. American Journal of Physiology 40, R848-R856

Thiele TE, Van Dijk G, Campfield A, Smith FJ, Burn P, Woods SC, Ilene L \& Seeley RJ (1997) Central infusion of GLP-1, but not leptin, produces conditioned taste aversion in rats. American Journal of Physiology 272, R726-R730.

Turton MD, O'Shea D, Gunn I, Beak SA, Edwards CMB, Meeran K, Choi SJ, Taylor GM, Heath MM, Lambert PD, Wilding JPH, Smith DM, Ghatei MA, Herbert J \& Bloom SR (1995) A role for glucagon-like peptide-1 in the central regulation of feeding. Nature 379, 69-72.

Van Strien T, Frijters J, Bergers G \& Defares P (1986) The Dutch Eating Behaviour Questionnaire (DEBQ) for assessment of restrained, emotional and external eating behaviour. International Journal of Eating Disorders 5, 925-315.

Villanueva-Penacarillo ML, Alcantara A, Clemente F, Delgado E \& Valverde I (1994) Potent glycogenic effect of GLP-1 (7-36) amide in rat skeletal muscle. Diabetologia 44, 1163-1166.

Welch IM, Saunders K \& Read NW (1985) Effect of ileal and intravenous infusions of fat emulsions on feeding and satiety in human volunteers. Gastroenterology 89, 1283-1297.

Wettergren A, Scholdager B, Mortensen PE, Myhre J, Christiansen J \& Holst JJ (1993) Truncated GLP-1 (proglucagon 78-107 amide) inhibits gastric and pancreatic functions in man. Digestive Diseases and Sciences 38, 665-673.

Willms B, Werner J, Holst JJ, Orskov C, Creutzfeldt W \& Nauck MA (1996) Gastric emptying, glucose responses and insulin secretion after a liquid test meal: effects of exogenous GLP-1 in type 2 diabetic patients. Journal of Clinical Endocrinology and Metabolism 81, 327-332.

Wolkowitz OM, Gertz B, Weingartner H, Beccaria L, Thompson J \& Liddle RA (1990) Hunger in humans induced by MK329, a specific periferal-type cholecystokinin receptor agonist. Biological Psychiatry 28, 169-173. 